\title{
ORGANIZATIONAL CULTURAL BARRIERS IN ERADICATING POVERTY THROUGH e-WARONG KUBE PKH
}

\author{
Yuce Sariningsih $^{1}$, Erti Dinihayati ${ }^{2}$, Uga Pratama Gunawan ${ }^{3}$ \\ ${ }^{1}$ Social Work Department, Universitas Pasundan, Indonesia \\ ${ }^{2}$ Business Administration Departement, Universitas Pasundan, Indonesia \\ ${ }^{3}$ Social Work Departement, Universitas Pasundan, Indonesia \\ ${ }^{1}$ yucesp@unpas.ac.id, ${ }^{2}$ ertidinihayati@unpas.ac.id, ${ }^{3}$ uga.pratama@unpas.ac.id
}

\begin{abstract}
This study used a survey to investigate the factors that influenced financial access and marketing ability and their implications for performance, and its effect on welfare of women's business group at e-warong Saluyu Ngawangun. e-Warong KUBE is a business group for poor women which was under supervised by Ministry of Social Affairs of the Republic Indonesia to eradicate poverty. The informant of this study were 10 (ten) poor women. To describe the Organizational cultural barriers in eradicating poverty through KUBE and e-Warong KUBE PKH used a qualitative approach. Organizational culture influences their performance and welfare level of a informant. Research finding showed that the application of entrepreneurship concept in managing both KUBE and ewarong KUBE PKH as small businesses have not been fully applied yet in addressing the problem of poverty. A small business badly necessarily entrepreneurial in nature, and to be an entrepreneurial means being creative and innovative to seek out new opportunities. Organizational culture as a beliefs, values, norms and behavior have not shared and practiced by organizational members yet. The recommendations based on research findings to strengthen organizational culture as followed: 1) Ministry of Social Affairs should have a social policy to improve entreprenuership spirit or e-warong, 2) Universities might improve entrepreneurship spirit of the KUBE's member and their business advisor by conducting business training.
\end{abstract}

Keywords: Organizational culture, creativity, innovation, financial access, marketing ability.

\section{Introduction}

Poverty in Indonesia is still quite high based on Indonesian Statistical Bureau (2020), it was about 28 million of the total 17 million occurred in the countryside. This means that approximately $60.71 \%$ of poverty occurs in rural areas; these conditions become a problem with the welfare status of rural communities. The entrepreneurial spirit to be one of the core instruments for the individual in carrying out efforts to raise up the people's economy level, which aimed to alleviate poverty in Indonesia as a result of the prolonged economic crisis. Entrepreneurship can be an important indicator of whether or not a country reflected their economic profile, however, entrepreneurship is still not yet popular by most people in Indonesia.

The increasing number of poor people lead increasingly low level of welfare of the population, but the entrepreneurial point are creativity and innovation as well as fighting spirit and endurance in carrying out small businesses are still weak, the concept of entrepreneurship to manage small businesses can not be applied fully yet in addressing the problem of poverty in Indonesia. Small businesses do not take fully into account related to the importance of the business knowledge that can be reached through training to improve their skills and quality of its business.

The skills that are related to the improvement of competence of the task is often not realized by them, although they were very motivated to work (Swasono, 2017). These condition as a reason of the Ministry of Social Affairs at the national level to address poverty by giving some grant to the poor women business group for alleviating economic activities problem by forming KUBE, which is in line with the 
concept of micro or small enterprises. The relevant institutions to carry out socioeconomic development through people's economy in the lowest strata of society, who must get the support from various parties especially supported by central and local governments.

Many people think that entrepreneurial venture and small businesses are one and same. However, there are some important differences between the two. Small business as one that is independently owned, operated, and financed; has fewer than 100 employees; doesn't engage in any new or innovative practices, and has relatively little impact on its industry. Meanwhile, entrepreneurial venture as an organization that is pursuing the opportunity, is characterized by innovative practices and has profitability and growth as its main goal. The implementation of poor women business group met some various constraints.

There was several issues related to the achievement of the business goals in the context of group work, which was dependent upon: 1) External parties, relating to the extent of the role and intervention of the government, the extent of the role and facilitate business world, and to the extent of the role and support of the group/nongovernmental organizations, the universities, and other parties that have concern for the poor, 2) Internal parties, associated with institutional quality of business group work, the ability of members in managing economic capital, marketing efforts, education and training, entrepreneurship, strategic partnerships, as well as other aspects (Sakarya, 2012.

Poor women business group prioritized on the realization of improvement entrepreneurship spirit on every member of the group, which is, in essence, to create creativity and innovation as a key component in turning the wheels of the business itself. Global economic conditions with a very tight competition and high-speed today to make creativity not only become an important source for the development of enterprises, but also a requirement for small businesses to continue to live. Mental barriers and feelings of guilt imposed on themselves can kill creativity and innovation, which is the essence of entrepreneurship. Meaning of innovations in research on poor women business group as a small business is not extraordinary innovation of the appearance of a product, but referred to innovation $n$ in accordance with the opinion of Alma (2008): "Innovation in small business is not remarkable findings, but a discovery that led to use economic resources more productive ".

Low levels of creativity, innovation and skill are the cause of failure of small and medium enterprises. It is also experienced by poor women business group to keep the business run and to get the benefit socially and economically. Many small businesses are experiencing failure and poor performance, such low of performance could be caused by their low capacity in managing financial and weak in marketing capabilities. Likewise, the problem experienced by business group work, weaknesses in the areas of financial. The weakness of small business in terms of the financial access are as follows:

1. The problem in seeking skilled employees; Small and medium companies may be able to provide high salaries but can not provide other warranties, such as large corporations. Small and medium companies do not have employee development program and promotion are very limited. This leads to loss the opportunity for the company to recruit well-qualified employees.

2. The difficulty of the capital increase; because the owner of the person or persons who provide capital very limited. Unlike large companies, small independent traders are not able to collect a large amount of capital. Expected cash flow may be sufficient for daily operations, but when will the expansion may be difficult to obtain capital (Glauh, 2011).

The benefits of the implementation of the business group have not yet felt up by the poor, the beneficiaries of funds business group likely to pursue another job after they cannot overcome the problem (Sariningsih, 
2021). The performance of poor women business group in running a small business have also considered not yet optimal. Many people have not actually been able to run a small business he started. Things turn off many businesses do not usually associated with a lack of money, talent or information, but more related to something more fundamental, that is a lack of understanding of business management, this condition is also found in poor women business group.

The cause of the failure of such entrepreneurs is the lack of knowledge and management experience (Coulter, 2001). Low level of performance in small businesses causes the business failure. In general, the business management process involves a series of economic choices, so that poor women business group need creativity and innovation to enable the movement of financial resources to support.

Another problem encountered in applying the concept of strategic management for small businesses is the insufficiency of capital to exploit external opportunities and cognitive thinking in daily operations (Danis, 2011). If poor women business group belong to small businesses, the need for creativity and innovation as a part of management strategic in running the business become crucial. Strategic management as a field of study is usually associated with large companies and wellestablished. However, small companies can not simply be ignored, because of the problem encountered in business management may cause further decline of small businesses.

The failure of the small business is often triggered by weak marketing efforts (Zimmerer \& Scarborugh, 2002). Although small entrepreneurs have ideas to improve marketing capabilities, but the inability of small entrepreneurs in setting a potential buyer can be an obstacle. One of the obstacles the success of small businesses which are many entrepreneurs who put forward the idea without specifying a potential buyer". Most marketing experts argue that the biggest marketing mistakes do small businesses are failing to clearly define the target market it will serve.

\subsection{The Importance of Entrepreneurship}

People talk about entrepreneurs as risk takers. On the contrary, good entrepreneurs are masterful at identifying risk and developing a plan to manage and offset risk. They must be creative to think in this fashion, and they must convince others of the correctness of their perception and plan. The more frequently practice this discipline, the better they become at it. Entrepreneurship has long been described by experts including the terms such as new, innovative, flexible, dynamic, creative, and risk-taking.

The stronger the leader, the more risk the individual is capable assuming, and the more responsibility that individual must marshal to creatively (and successfully) manage the risk (Sariningsih, 2021). Individual leadership equals empowerment. That is, the more leadership an individual exhibit, the more responsibility they will assume. Responsibility is what makes an individual feel empower. There is much banter about "empowerment" in the workplace. This is especially true in what are deemed entrepreneurial environments.

Creativity and innovation are the core of entrepreneurship, and creativity has a close connection with innovation. Poor women business group was expected to improve the socio-economic conditions for the lower strata of society to improve living standards, as well as well able to cope with social unrest caused by the helplessness and inability economy.

The close relationship between creativity, innovation and skills in business development as follows: "Creative thinking and innovative has been the core business skills, and entrepreneur become a leader in the effort to develop and apply these skills. In fact, creativity and innovation are often at the heart of the ability of small companies to compete with their larger competitors (Zimmerer \& Scarborugh, 2002).

Creativity and innovation are also the criteria for social assistance activities in the implementation of business group work so 
that members are expected to have the creativity and innovation are also high.

Every business group work has a distinctive and specific characteristics, both of resources, customs, and the habits. Therefore, in addition to social welfare should be able to explore the potential for harnessing KUBE to be a source of empowerment, should also be able to develop creativity and innovation in order to improve the ability of members of KUBE in recognizing and utilizing potentials. Creativity and innovation, in the end, became the destination of the business group work member in running their business (Ministry of Social Affairs RI, 2016). To distinguish between creativity and innovation is simply to say that the new thing thinking creativity, innovation doing new thing,

The ability to apply creative solutions to problems and opportunities to improve or enrich the lives of people (Zimmerer \& Scarborough, 2002). Innovation and creativity are the main functions in the entrepreneurial process. Entrepreneurs can combine imaginative and creative mind with the ability of a logical and systematic process. Potential entrepreneurs are always looking for a unique opportunity to meet the needs and desires. Creativity and innovation are two concepts that are not separate,. Creativity is a new idea, whereas innovation is the commercialization or application of new ideas. To create a more innovative business, business group work must develop an entrepreneurial culture as a culture that is open to new technology transfer into products and business activities. Business group work must be flexible, able to accept change and be willing to accept failure as the path to success. Innovation is the result of a search of a chance to do it wholeheartedly.

For centuries, business has felt the need to create new products (Sun, 2012). Successful innovation is generally simple and focused and is aimed at applications that are designed distinctive, clear and accurate. Innovation involves more physical work than thought. Innovations for more entrepreneurs are utilizing a change rather than create it. Looking for innovation is done by utilizing a change in the discovery that caused the changes. The innovative idea can be soured on the creativity of external and internal creativity. Innovative efforts need to be done continuously even though an organization or company has successfully achieved its objectives. Matrix market new products, whether goods or services, the better are the perfect tool for innovation.

Innovation is a process of changing, experimenting, transforming and revolutionizing". It is one of the key distinguishing characteristic of entrepreneurial activity (Coulter, 2000). The creative destruction process that's inherent in innovating leads to technological change and employment growth. The passionate drive and intense hunger of entrepreneurs to forge new directions in products and processes and to take risks set in motion a series of decisions and actions that lead to the innovations that are important for economic vitality. Without these new ideas, economic, technological, and social progress would be slow indeed.

\subsection{The Idea of Innovation}

Management includes planning, organizing, leading, and controlling of human activities and the management of limited resources, necessary to achieve organizational goals efficiently and effectively. In an organization, which is essentially a collection of people who work together and coordinate their actions to achieve the goals or outcomes in the future needed a manager, responsible for the supervision of the use of those resources. Organizational resources include assets such as skills, knowledge, production machinery, raw materials, computer and information technology and financial capital, which must be managed efficiently and effectively. Efficiency is a measure of how well or how resources are productively used to achieve goals. Effectiveness is a measure of the appropriateness of the goals that managers have selected for the organisation to pursue and of the degree to which the organisation Achieves Reviews those goals (Jones \& George, 2020). It is a measure of how well or to what extent the existing resources are used productively to achieve the goal. While 
effectiveness is a measure relating to the ability of managers to determine organizational goals that can be achieved, and determining to what degree the organization to achieve its objective. Effective managers are capable of accurately determining the organizational goals and achievable, and have the skills to manage resources efficiently. Core managerial functions which include planning, organizing, leading and controlling must be implemented by managers at all levels and departments, whether it is large or small organizations, for-profit or non-profit is still expected to show all four functions. The extent to which the manager displays the functions that can be an indicator of the efficiency and effectiveness of the organization manages.

Innovation is the specific instrument of entrepreneurship. It is the act that endows resources with a new capacity to create wealth. Innovation, indeed, creates resources. There is no such thing as a "resource" until man finds a use for something in nature and this endows it with economic value. Innovation does not have to be technical, does not indeed have to be a "thing" altogether. Few technical innovation can compete in terms of impact with such social innovations as the newspaper or insurance. Then, it is an economic or social rather than a technical term where the modern economist would tend to do. It can be defined in demand terms rather than in supply terms, that is, changing the value and satisfaction obtained from resources by the customer.

Change and innovation are passionate processes. Successfully planned change requires a commitment grounded in an engaging vision and deep emotional involvement with the program (Poole \& Van de Ven). An efforts to address the creativity and innovation is by strengthening the entrepreneurial mentoring, access to capital and product marketing. The concept of team building counterpart in the implementation of productive economic activities through connecting KUBE in the context of Intellectuals, Business and Government (IBG) to improve the creativity, innovation and skills KUBE. Productive business activities through KUBE is one of the activities to achieve the community welfare.

In general, KUBE program aims to tackle poverty through community empowerment by moving the local economic potential to the society itself, in synergy with the existence of cooperatives to development capital, the expected outcome is the impact the welfare of the surrounding community. Along with the importance of cooperatives in the business group work existence as a democratic economy, The economy is the people who should be the rest of the nation, the economy based on the strength and local content through the optimization of resources and the domestic market. Cooperative worth thinking about as the internal organization of society which will move the economy people at lower levels. The Democratic economy must also be supported by major capital in the form of entrepreneurial spirit and skills as a human capital, so as to enhance the ability of capital and marketing, the member of business group work could be further to improve performance and ultimately to reach a prosperity for better society.

Another efforts to improve creativity and innovation are to develop a personality profile of the entrepreneur, one list of personality characteristics included the following:

1. High level of motivation

2. Abundance of self-confidence

3. Ability to be involved fo the long term

4. High energy level

5. Persistent problem solver

6. High degree of initiative

7. Ability to set goals

8. Moderate risk taker

Another list of characteristics of "successful entrepreneurs" included high energy level, great persistence, resourcefulness, the desire and ability to be self-directed, and relatively high need for autonomy.

\subsection{Organizational Culture Issues}

Every particular business will try to get certain impression about whats important of product and about the way work is done by organizational members. The feeling that members are excited and motivated by what 
they do in business is very cruacial, or that members are there just because it's paycheck coming in, does it seem that members are seen as intrussions on getting work done. Other business environment are the feeling that this organization is warm, relaxed and open, instead of organization structure which is inflexible and very rigid. The organization should is formulated in form pf more formal or more informal, so that individuals have personalized in organization also has a personality, that is culture, just as every person has or his or her own unique personality, every organization as KUBE and e-warong KUBE have a unique personality.

Exactly, what is organiziational culture? It's belief, values, and behavior or norms shared and practiced by organizational members (Coulter, 2000), even in an business organization that includes the entrepreneur, certain beliefs, values, berhavior and norms will influence how decisions are made and work is completed. This condition will lead to shared beliefs, values and behavior and norms that make up an organization culture determine, to a large degree of business, what organizational members perceptions is important and the way they do their work. When confronted with many problem, the organizational culture take an important role and influences what organizational members do about it.

\section{Method}

The study employed qualitative approach (Miley \& O’Melia \& DuBois, 2017) conducted in $e$-Warong KUBE Saluyu Ngawangun Kota Cimahi. The informants are 10 (ten) business woman consist of 1 person as team leader, 1 person as secretary, 1 member as treasurer and the others as members of e-Warong KUBE Saluyu Ngawangun Kota Cimahi.

The data gathering used indepth interview at e-Warong KUBE Saluyu Ngawangun Kota Cimahi. For research validity employed construct validity and triangulation. The data analysis used to coding and category process of data finding. Code means the label attach to a phrase or other short sequence of the text are analysing. Category is a grouping impose on the coded segments, in order to reduce the number of different pieces of data in analysis.

\section{Results and Discussion}

\subsection{Entrepreneurship and Poverty Eradication in Developing Countries}

Very worthy of mention the issue of minority and women-owned businesses in developing country. The more generic issue was the gender problem, the marginalization of women entrepreneurs was regarded as commonplace. However, in recent times, increasing the sensitivity of policy makers was witnessed for women entrepreneur. There are also nongeneric issues such as culture and values of some Asia Pacific economies which come in the way of women entrepreneurship development.

Indonesia currently has only $0.18 \%$ of entrepreneurs (entrepreneurs) of the population. In fact, the developed countries should have at least $2 \%$ of the population engaged in the entrepreneurial sector (http: //wikipedia.web.id, 2019). A number problems and constraints which include the following among other:
1. Lower productivity and outdated technology;
2. Lower economies of scale;
3. Lack of modern marketing;
4. High cost of domestic credit and lack of foreign investment;
5. Increased competition;
6. Lack of skilled labor and managerial skills and competencies;
7. Globalization issues; and
8. Constraint on infrastructure

Another major concern is that Small Medium Enterprises in Thailand lack entrepreneurial knowledge. The National Economics and Social Development board have identified that the lack of management skills is one of the biggest challenge (Ndubisi, 2008). Generally, the most problem faced by small scale industry cannot compete in low-end markets with the lower labor cost competitor.

3.2 Kelompok Usaha Bersama (KUBE) Poverty is the basis for economically productive activities grant program through the Business Group (KUBE). Addressing 
poverty requires cooperation, support, and synergy of all stakeholders, including local government sector, civil society, and the business world, so the intertwined unity of movement steps to jointly improve the ability of the poor to access sources of material, intellectual and information optimally.

Definition and scope of poor women business group (KUBE) according to the Ministry of Social Affairs of the Republic of Indonesia are as follows:

1. Business Group (KUBE) is a group of citizens or socially assisted family formed by citizens or socially assisted family that has been fostered through the process of Social Welfare Program (PROKESOS) to carry out activities of social welfare and economic efforts in the spirit of togetherness as a means to improve social welfare.

2. KUBE an integrated approach and the overall process of implementation of the Social Welfare Program (PROKESOS).

KUBE formation begins with the process of group formation as a result of social assistance, business skills training, assistance and mentoring stimulant. At the provincial level, productive business through Business Group (KUBE) organized by the Social Service Department of West Java Province. KUBE is a community empowerment in national economic development, which in the future is expected to be embryo SMEs and stimulate the economy with social welfare issues. One type of KUBE KUBE is a woman, based on consideration for women as the economic backbone of the family

Most small business owners do marketing moves direct to every customer that encountered in the effort that some of the prospective buyers would be interested. This approach can no longer be used when the business is growing. poor women business group expected to develop their entrepreneurial spirit to promote small business they started, as well as being an innovator is able to utilize and transform opportunities into ideas that can be sold or marketed, adds value by leveraging the effort, time, cost or skills in order to gain profit. Therefore, it is necessary to increase the managerial ability to organize productive economic activities, to develop operational capabilities, obtain funds for venture capital and manage business activities. In addition, it is necessary to increase the technical knowledge to realize ideas, thus expected to combine creative thinking and imaginative capabilities logical and systematic process, which is key to the success of this fusion productive economic activities.

Productive business can expand marginalized communities to access capital slightest, such access has a transformative effect on human lives. Over time, many people with limited ability of capital were able to use a small capital loan as the basis to build a lasting, in the form of a plot of agricultural land, farms, food industry, craft workshops or small shop, which can be lifted out of poverty. Access to capital can ultimately increase the incomes of the poor. Goals and objectives of the activities organized by the Business Group (KUBE) refer to the Guidelines and Technical Guidance, Social Services West Java (2008), as follows:

1. Enhancing capability in fulfilling the needs and improvement of social welfare of members.

2. Enhancing KUBE members in addressing the problems that occur in the family and social environment.

3. Improving the ability of members of KUBE in displaying his social role.

While the targets KUBE program is a group of poor families or certain people who will get help Social Guidance and Skills, Productive Economic Enterprises aid stimulant intended for:

1. KUBE for Needy Families

2. KUBE for Vulnerable Families

3. KUBE for Poor Women

4. KUBE for Juvenile

5. KUBE with Disabilities

6. KUBE for Neglected Children

7. KUBE for the Elderly

8. KUBE for Youth

9. KUBE for Orphan

10. Communication Forum Community Social Worker. 
The productive business developed covering the fields of agriculture, animal husbandry, fisheries, forestry, household industry, services and other economic activities. The activities carried out in the form of venture capital assistance in the form of economic infrastructure and the benefits of living channeled directly or through the mechanism of banking. The establishment and development of a KUBE implemented within five (5) stages:

1. Preparation; The activities in the preparatory phase consists of orientation and observation, registration and identification, planning, program implementation, general social counseling, guidance problem recognition, motivation and evaluation guidance preparation (which is done by the village officials, officers, and supervisors functional companion).

2. Implementation Phase; The activities during the implementation phase includes the selection of candidates for Families Patronage Social (KBS), the establishment of pre-group and group selection / determination of the type of business, training companion, skills training members of KUBE, relief food or compensation / life insurance, assistance stimulant capital, mentoring and evaluation (conducted by village officials, escort officers, supervisors functional and relevant agencies).

3. The phase of Business Development; The activities at this stage of business development covers business development guidance, provision of business development assistance, mentoring and evaluation (conducted by officers' escort and clerk functional builder).

4. Stage Business Partnership; The activities at this stage include an inventory of the resources that exist (natural resources, economic resources, social resources and human resources), making agreements execution of business partnerships, expansion of the network of business partnerships and evaluation (conducted by the mentor and adviser functional).

5. Monitoring and Evaluation Phase; the activities at this stage include process control and monitoring ongoing implementation and evaluation of the success that has been achieved (implemented by escort officers and supervisors functional).

Target activities through the Productive Economic Business Guidance for WRSE $K U B E$ are women with the criteria and requirements as follows:

A. Criteria:

1. Age 17-50 years;

2. Widows as a head of household or live alone;

3. Women who became head of the household;

4. Women as the main breadwinner in the family (wife whose husband left indefinitely, and or pain that can not work for a living);

5. Income less or do not meet the minimum physical needs;

6. The education level is low (usually a maximum of completion of primary education).

B. Requirements

1. Based in the village designated as the location of activities;

2. Physically and mentally healthy;

3. Classified women who have low incomes.

4. Have expertise and skills in the Productive Economic Business (UEP) which allows developed technically and operationally.

5. Never fostered by the Social Welfare Program, implemented by both Social Agency of West Java and West Java Provincial Office of Social Ministry.

6. Interested, honest, willing to cooperate in activities Productive Economic Enterprises.

7. Willing to manage relief efforts in the form of Productive Economic Enterprises in KUBE.

KUBE institutional structure depending on the type of business you run, so there is no standard structure, yet simple organizational structure that can be used as a reference refers to the Guidelines for the Implementation and Technical Guidance, Social Services Provincial Government of West Java (2008) consisted of: 
1. Chairman

2. Secretary

3. Treasurer

There were 37 groups and 360 member

of KUBE in West Java, each group received grant from Ministry of Social Work as business stimulant, the data as described in the following table:

Table 1. List of KUBE at West Java

\begin{tabular}{|c|c|c|c|}
\hline Location & $\begin{array}{l}\text { Address (Sub- } \\
\text { District) }\end{array}$ & $\begin{array}{l}\text { Kind of } \\
\text { Business }\end{array}$ & Member \\
\hline Bandung & 1. Ciparay & Bag Craftsmen & 10 \\
\hline \multirow[t]{9}{*}{ Regency } & Ciparay & Bag Craftsmen & 10 \\
\hline & Margahayu & Food vendors & 10 \\
\hline & Katapang. & Tailor & 10 \\
\hline & Katapang. & Tailor & 5 \\
\hline & Katapang. & Food seller & 10 \\
\hline & Pacet. & Daily product & 10 \\
\hline & Pacet. & Bag Craftsmen & 10 \\
\hline & Kutawaringin. & Food seller & 5 \\
\hline & 10. Cileunyi & Food seller & 10 \\
\hline Majalengka & 1. Maja. & Crackers & 10 \\
\hline \multirow[t]{4}{*}{ Regency } & Maja & Crackers & 10 \\
\hline & Dawuan & Sheep farmer & 10 \\
\hline & Dawuan & Sheep farmer & 10 \\
\hline & Dawuan & Sheep farmer & 10 \\
\hline \multirow[t]{10}{*}{ Garut Regency } & 1. Kersamanah. & Crackers & 10 \\
\hline & Garut & Batik & 10 \\
\hline & Karangpawitan. & Craft & 10 \\
\hline & Karangpawitan. & Craft & 10 \\
\hline & Banyuresmi & Crackers & 10 \\
\hline & Banyuresmi & Noodle & 10 \\
\hline & Banyuresmi & Crackers & 10 \\
\hline & Garut & Cake & 10 \\
\hline & Garut Kota & Crackers & 10 \\
\hline & Kota & Coconut sugar & 10 \\
\hline Kuningan & Kadugede & Sheep farmer & 10 \\
\hline \multirow[t]{2}{*}{ Regency } & Kadugede & Daily product & 10 \\
\hline & Kadugede & Salon & 10 \\
\hline Ciamis & Cidolog & Tailor & 10 \\
\hline \multirow[t]{2}{*}{ Regency } & Cidolog & Embroidery & 10 \\
\hline & Cidolog & Embroidery & 10 \\
\hline \multirow[t]{3}{*}{ Banjar City } & Langensari & Sheep farmer & 10 \\
\hline & Langensari & Dried banana & 10 \\
\hline & Langensari & Dried banana & 10 \\
\hline \multirow[t]{3}{*}{ Cirebon City } & Lemahwungkuk & Daily product & 10 \\
\hline & Lemahwungkuk & Daily product & 10 \\
\hline & Lemahwungkuk & Daily product & 10 \\
\hline Total & & 37 Groups & 360 \\
\hline
\end{tabular}

The previous data of KUBE showed that there were several kind of business consist of crackers production, sheep farmer, batik craftmen, daily product and the like.

Based on KUBE business, Ministry of Social Affairs then develop program to eradicate poverty in urban are namely ewarong KUBE $\mathrm{PKH}$, which used digital transaction in their business operation. Which is supported by Association of State Bank of Indonesia (Himpunan Bank Negara /HIMBARA). It is also collaborated between several parties, that is Ministry of Social Affairs, Ministry of Financial Affairs and other parties.

\section{2 e-Warong Kelompok Usaha Bersama (KUBE) PKH}

e-Warong (electronic Warung Gotong Royong Kelompok Usaha Bersama (KUBE) Program Keluarga Harapan (PKH). ewarong is a term used in the Non-Cash Assistance Program which refer to bank agents, traders and/or other parties who have collaborated with channeling banks and are 
determined as places to purchase food by Beneficiary Families (KPM), namely traditional markets, food stalls, grocery stores, KUBE e-warongs, Warung Desa, Rumah Pangan Kita (RPK), Laku Pandai Agents, Digital Financial Service Agents (LKD) that sell food or other retail businesses.

$e$-warong is a community empowerment program in the economic field through the Prosperous Indonesia Community Card issued by BNI, it is hoped that the empowerment of the poor towards a prosperous society can be realized. This program facilitates economic transactions for the recipients of the Family Hope Program (PKH). The amount of non-cash food assistance is $\mathrm{Rp}$. $110,000,0 / \mathrm{KPM} / \mathrm{month}$, this assistance cannot be taken in cash, and can only be changed with rice and/or eggs at e-warong. If the aid is not spent in that month, the money value of the aid will still be stored and accumulated in the his/her Food Aid Electronic Account. The differences between KUBE and e-warong KUBE PKH describes as follows:

Tabel 2. The differences between KUBE and $e$-warong $K U B E$ PKH

\begin{tabular}{lcc}
\hline Component & KUBE & e-Warong \\
\hline Members & 10 persons & 10 persons \\
\hline Transaction Process & Manual & $\begin{array}{c}\text { Electronic Data } \\
\text { Capture (EDC) }\end{array}$ \\
\hline Location & Urban and rural & Urban \\
\hline Business Variable & & \\
Creativity & Low & \\
Innovation & Low & \\
Skill & Quite high & \\
Financial access & Low & \\
Marketing ability & Low & \\
Performance & Low & \\
Organizational & & \\
Culture & & Low \\
Innovation and Risk & & \\
taking & & Low \\
Attention to detail & & Low \\
Outcome orientation & & Low \\
People Orientation & & Low \\
Team Orientation & & Low \\
Aggresiveness & Low \\
Stability & & Low \\
& &
\end{tabular}

Source: Research finding, August 2020.

From the previous data of business variable as shown in table 2 described that there were no significant different of performance both at KUBE and e- warong KUBE based on the data of business variable (consist of creativity, innovation, skill, financial acees, marketing ability and performance) according data taken from the previous research mentioned earlier, and organizational culture in e-warong. Each of cultural dimensions exists on a continuum from low to high, and all the dimension of $\mathrm{e}$ -warong is in low continuum.

According to research into organizational culture suggest that seven dimensions capture the essence of oragnization's culture as illustrated below (Coulter, 2000):

1. Innovation and Risk taking: The degree to which employees are encouraged to be innovative and take risks; 
2. Attention to detail: The degree to which employees are expected to exhibit precision, thorough analysis, and attention to detail;

3. Outcome orientation: The degree to which results and outcomes are considered more important than the techniques and processed used to achieve those outcomes;

4. People Orientation: The degree to which organizational decisions take into consideration the effect on organizational members;

5. Team Orientation: The degree to which organizational work is done in teams rather than by individuals;

6. Aggresiveness: The degree to which organizational members are aggressive and competitive instead of easygoing and cooperative;

7. Stability: The degree to which organizational decisions and actions emphasize maintaining the satus quo as opposed to growing.

The development of an entrepreneurial culture implies their mental attitude to come forward as much as possible in carrying out productive economic activities

\subsection{Organizational Culture of $\boldsymbol{e}$-Warong KUBE}

Describing e-warong on these seven dimensions provides a composite picture of its culture. In many organizations, one cultural dimensions often takes precedence over the others and essentially shapes the ewarong and the way its members do their works. The personalities of e-warong reflect the cultural dimensions that is valued and prized as entrepreneur.

The entrepreneur needed an ability to perform a particular task, both physically and mentally (Coulter, 2000). Creativity and innovation are also related to the skills where entrepreneurs are expected to emerge from the economic activity through productive economic activities are expected as an entrepreneur who has the skills, especially e-warong as entrepreneurs must have the power of entrepreneurial skills. Skills are an important component in the development of the business, in line with it can be said that the level of skills of an entrepreneur affected the successful on increasing the financial access and marketing. Skills possessed by the respondent at the time of technical skill alone was likely to produce a product. These skills must be developed constantly and go into a loop.

\section{Innovation and Risk Taking:}

The data degree to which e-warong members are encouraged to be innovative and take risks showed a low level. When referring to the type of business that is managed by the informants, it was explained that most of them manage the business which was classified in the creative industry, that is the industries which rely on elements of talents, skills, and creativity. These three elements are a fundamental element of the individual so that everyone has a basic capital equal and free. By optimizing the utilization of the creative potential of these three elements, then means it has participated in the efforts to increase the capacity (capacity building) of e-warong human resources.

The creativity that generated innovation is often associated with the mastery of high technology. It is the old paradigm. Innovation could also not of technology but of new value generated. Innovation can be achieved by the creation of new value that can be created by micro enterprises as e-warong, though. Development with a capital of creativity that is focused and effective, in the long term will be able to increase growth and equity (growth and equity), so as to improve the quality of life (well-being) through community empowerment. As the creative industry is very responsive to absorb the accumulation of social phenomena in society and poured into context in the form of products and services such as fashion apparel products and crafts and entertainment products, agriculture product and so on.

\section{Attention to Detail}

The degree to which e-warong members are expected to exhibit precision, thorough analysis, and attention to detail is in low level. Attention to detail is e- 
warong ability to efficiently allocate their cognitive resources to achieve thoroughness and accuracy when accomplishing tasks, no matter how small or large of business. Attention to detail skills allows e-warong to improve their workplace productivity, efficiency and performance in creative economy. Besides, To develop the creative economy in e-warong, the concept of the actor is very important, they are scholars (intellectuals), business (business) and the government (government), or the abbreviated IBG. Referring to the above opinion, to achieve the ability of capital in accordance with the indicators KUBE, then the respondent should be assisted by a team of a business counselor who will assist theKUBE member to emerge creativity, innovation, and skills. The business counselor team also must understand the interaction between scholars, business, and government to improve the financial access and marketing ability.

\section{Outcome Orientation}

The degree to which results and outcomes are considered more important than the techniques and processed used to achieve those outcomes in e-warong is still in low level. Outcome-oriented cultures of e-warong as those that emphasize achievement, results, and action as important values. E-warong should be trained to sell company products effectively, and they learn how much money their department made every day.

These three components interact in a system greatly affect creativity, innovation and skills of informants in improving the ability of capital development. Strengthening the financial business counselor team in enhancing creativity, innovation, and skills of respondents in carrying out productive economic activities is very important, it is also on the consideration that the respondents have low education levels and as the economic backbone of the family. The team basically as a motivator and provide insights on entrepreneurship and skills training, which consisted of voluntary who has a knowledge in business and representatives of universities/academics (realize a variety of activities related to management, helping to make the design of the loan application of venture capital and establish relationships with banks facilitator in the formation of cooperatives, to establish business networks with business partners, facilitate access to funding populist economic development of Corporate Social Responsibility (CSR), and other activities related to the acceleration of capital), and other relevant experts if necessary.

\section{People Orientation}

The degree to which organizational decisions take into consideration the effect on organizational members of ewarong is in low level. E-warong culture can be partially defined by the members' behavior when they are not under direct supervision and act on their value-based instincts. The concept of a more "peopleoriented" culture is in opposition to traditional models based on hierarchical systems and productivity, and nowadays the traditional model is gone. And so is the idea of repaying a member's loyalty with continued permanent employment. Prominent aspects of this type of organizational culture include which should exist in e-warong are:

- High levels of empathy

- Recognition and praise

- A positive work environment

- The ability to give and receive constructive feedback

- High levels of employee engagement

- Employee success is taken seriously

- Employees feel respected and valued

Authenticity and transparency are also essential to enable communication in the workplace and ensure that everyone. Creating an e-warong culture involves selecting a series of values that should be defined by $e$-warong itself and the products it stands to represent. As a leader, head of e-warong need to 
encourage those values in her employees' everyday behaviors.

\section{Team Orientation}

The degree to which organizational work is done in teams rather than by individuals in e-warong is in low level. Creating a team-oriented environment can seem like a daunting task. In today's workplace, employees can find themselves competing against each other instead of helping one another out, and in the end everyone's performance suffers for it.

As a team leader of e-warong, it's your job to take your employees to the highest level of performance, doing this by creating an environment that plays on everyone's strengths and creates a culture of excellence, with orientation to place importance on having a family culture and helping one another. The team leader can create this kind of culture in e-warong by focusing on these five major characteristics.

- Knowledge: e-warong has multiple areas that people can be experts in. Find out what areas of knowledge needed and create those experts, then help them go beyond a surface level of understanding. Not everyone needs to know everything, so encourage your members to focus on a specific area of knowledge. Make sure they know to whom and when to pass on a problem that another members would be best at handling. That way, you can cultivate the member's knowledge while helping them be autonomous in their specific areas.

- Professionalism: Team leader may be able to teach knowledge to members, but be carefull that soft skills can be the make or break piece of the equation. Shows the professionalism is one of these to having team members understand the importance of politeness and reliability is priceless. Improve the member's skills through training.

- Positive Attitude: Team leader and members can create an environment of business, but it's one tiny and crucial step further to create an environment of solutions. Team members should know and be able to take that extra step, because when members are proactive, it creates a community where people want to come to work every day. It will help to market various product of e-warong.

- Active Listening: Listening to member 's problem privately by team leader can be just as important as listening to customers. When there's tension in warong, it shows, and everything else is tainted by that strain. Encourage your members to show interest in each other, and they'll show more interest in the job they're doing as well. Ultimately, this way will help them feel like they're all in this togetherness, because they are.

- Taking Initiative: A great member does more than reacting to problems as they come, however they take proactive steps to create a better customer and employee experience. When the member react to a problem, they are thinking of the past, but when they proactively approach the problem, means thinking of the future. Every time a member takes initiative, they makes the e-warong environment just a little bit better for those around them. When everyone takes initiative together, it can change your business environment completely

\section{Aggresiveness:}

The degree to which organizational members are aggressive and competitive instead of easygoing and cooperative in e-warong is in low level. This 
characteristic dictates whether members in e-warong expected to be forceful or not when dealing with competitors. Companies with an aggressive organisational culture will strive to outperform their competitors at all costs.

\section{Stability:}

The degree to which organizational decisions and actions emphasize maintaining the satus quo as oppose in ewarong is in low level. A culture of stability is at the inner point of every dimension. Expect members operating in a culture like this to care about order and safety, to be reactive and follow purpose and rules as written. These people will do what team decision tell themselves to do and not much more, which is exactly what the team member want.

Organizational culture which include belief, values, behavior and norms in every dimensions as shown on table 2 reflected in a low level. First, individual as members of e-warong perceive the culture of the organization on the basis of what they see, hear, or experience within the organization. Even though their members may have different backgrounds, work and motive in different areas in the organizations, they tend to describe the organization's culture in similar terms according to their environment. That is what the important shared aspect of culture. Second, organizational culture is a descriptive term which is members want. This condition will lead to the culture which concerned with how organization members perceive organization, not with wether they like it. Every member should adapt with business culture to achieve an excellent performance of warong KUBE PKH.

\section{Conclusion}

The recommendation of this study to improve performance for both KUBE and ewarong KUBE PKH was directed to Academic Community, Business Sector and Government (Ministry of Social Affairs Republic of Indonesia) as followed:

- Ministry of Social Affairs Republic of Indonesia as government representative should improve their entrepreneurship spirit by conducting business training, and strengthening organizational culture.

- Universities as representative of academic community should carry out a community service related to entrepreneurship;

- Business sector should develop a program based on Corporate Social Responsibility Program for business development.

\section{References}

Coulter. Mary K. 2001. Entrepreneurship in Action. New Jersey; Prentice Hall, Inc.

Danis, W.M., De Clercq, D. \& Petricevic, O., 2011. Are social networks more important for new business activity in emerging than developed economies? An empirical extension. International Business Review, 20(4), pp.394-408

Glaub, Matthias; Frese, M., 2011. A critical review of the effects of entrepreneurship training in developing countries. , 22(4), pp.335 353

Hay, R. \& Gray, E., 1974. Social

Responsibilities of Business Managers. Academy of Management Journal, 17(1), pp.135-143.

Indonesian Statistical Bureau (2020

Jones, Gareth and George, Jennifer. 2020. Contemporary Management $11^{\text {th }}$ Edition. New York: McGraw Hill

Ministry of Social Affairs RI (Kementrian Sosial RI.) 2019. Kelompok Usaha Bersama (KUBE). Jakarta: Kemensos.go.id

Ministry of Social Affairs RI (Kementrian Sosial RI.)., $2016 . \quad$ Petunjuk Pelaksanaan E-Warong KUBE. Jakarta

Ministry of Social Affairs RI (Kementrian Sosial RI.). 2017. Instrumen B https://ejournal.kemsos.go.id/index.php /SosioKonsepsia/article/downloadSu ppFile/1422/116

Miley, Karla Krogsrud \& O’Melia, Michael W \& DuBois, Brenda L. Eighth Edition 2017. Generalist Social Work Practice, an Empowering Approach. Boston: Pearson

Rubin, Allen \& Babbie Earl R. 2017. Research Methods for Social Work. Boston: Cengage Learning 
Richardson, R., 2010. 360-Degree Feedback: Integrating Business KnowHow with Social Work Values. Administration in Social Work, 34(3), pp.259-274

Sakarya, S. et al., 2012. Social alliances: Business and social enterprise collaboration for social transformation. Journal of Business Research, 65(12), pp.1710-1720.

Sariningsih Y, Purwanti $\mathrm{Y}^{\mathrm{a}}$ and Dinihayati E.. 2021. Waste Bank as Business Development Solution in e-warong KUBE PKH. Published under licence by IOP Publishing Ltd. https://iopscience.iop.org/article/10.10 88/1755-1315/737/1/012062

Sun, L.Y. et al., 2012. Empowerment and creativity: A cross-level investigation. Leadership Quarterly, 23(1), pp.55-65.

Swasono, Sri Edi. 2017. Ekspose Ekonomika, Mewaspadai Globalisasi dan Pasar Bebas. Jogjakarta: Pusat Studi Ekonomi Pancasila.

Swasono, Sri Edi. 2015. KeIndonesiaan, Demokrasi Ekonomi Keberdaulatan dan Kemandirian. Jogjakarta: Universitas Sarjanawiyata

Yanthuridi, Turtiantoro. 2017. Implementasi Program e-Warong KUBE PKH di Kota Semarang https://ejournal3.Undip.ac.id.

Zastrow, Charles. Twelfth edition. 2017. Introduction to Social Work and Social Welfare, Empowering People.. Boston: Cengage Learning

Zimmerer Thomas W \& Scarborough, Norman M. 2002. Essentials of Entrepreneurship and Small Business Management, 3rd Edition. New York: Pearson 